importance of Polynesian, and particularly Maori, studies. He maintained that the white people should learn the language and appreciate to a greater extent the mental and spiritual outlook of the Maori people. While he regretted that it is no longer true, as it was thirty years ago, that at least one third of the Legislature is acquainted with the Maori language and outlook, he hoped that improvement would come from the endowment left to promote knowledge of the manners, customs and language of the Polynesians by the late Prof. Macmillan Brown, whose enlightened aspirations had given him personally immense encouragement.

\section{Recent Archæological Finds in Ireland}

AN authoritative article on recent Irish excavations by Mr. Sean F. O'Riordan, of the National Museum of Ireland, appears in the April number of Discovery. During the year 1934, the National Museum received an unusual number of accessions of exceptional interest as the result of easual discovery. Among these were the remarkable gold gorget of about 700 B.C. from Co. Clare, the bronze age wooden shield-only the second known-from Co. Mayo, the fine Middle Bronze Age rapier from Co. Tipperary and much noteworthy Viking material from Co. Dublin. The greatest advance in the study of Irish archæology, however, has been due to the participation of archæologists in carrying out the Government's scheme for unemployment. This has made possible systematic investigation on an extended scale on an unprecedented number of sites. No less than twelve excavations were carried out in various parts of the country, ranging in date of the period under investigation from post-glacial times to the fifteenth century A.D. The number of workmen engaged on individual sites in these operations varied from twelve on the smallest to fifty on the largest.

The results of the investigation of the sequence of events in post-glacial times at Ballybetagh are already well known, owing to the interest aroused by the pollen analysis, though the report is not yet complete. Another investigation of wide general interest, although purely negative in result, is that in the cave of Kilgreany, Co. Waterford. Some years ago members of the Bristol Spelæological Society claimed to have found there human remains of palæolithic age. The present investigation has not substantiated this, and evidence of palæolithic man in Ireland is still to be sought. Questions of major interest are also solved at Cush, near Kilfinane, Co. Limerick, where for the first time ring forts were found in a series of six, a souterrain was for the first time definitely dated so early as pre-Late Bronze Age, and the Irish town, previously not known before Viking times, was shown to have existed so far back as the Bronze Age.

\section{Major-General A. W. Greely}

The American explorer Major-General A. W. Greely, who has just reached the age of ninetyone years, is reported by The Times to have been awarded the Congressional Medal of Honour of the United States for heroism on his Arctic expedition of 1881-84. That expedition was the contribution of the United States to the International Polar Stations of 1882-83. Under Lieut. Greely's leadership, three officers and nineteen men were landed in Discovery Harbour in Grant Land (Ellesmere Island). The main objects were meteorological and magnetical observations, but Lieuts. Greely and Lockwood carried out extensive explorations in Grant and Grinnell Lands, and Lieut. Lockwood made the northern record to lat. $83^{\circ} 24^{\prime} \mathrm{N}$. The relief ship was prevented by ice from reaching the camp in 1882 and again in 1883. Lieut. Greely then decided to retreat to the south with much depleted equipment and scanty stores. Near Cape Sabine in Smith Sound, they passed their third winter. Already scurvy had taken a heavy toll and the remaining men were scarcely able to hunt; fuel and food were practically exhausted when in June 1884 relief reached them in the Thetis. Only seven men were alive; not one could walk without assist. ance and at the time there seemed little likelihood of any living long enough to reach an American port. General Greely was awarded the Founder's Medal of the Royal Geographical Society in 1886 for the excellence of his Arctic work.

\section{Henry Fuseli (r74I-1825)}

A RENEWED interest in the work of the Swiss artist Henry Fuseli (1741-1825) is being taken at present through an exhibition of some of his paintings and drawings at Ryder Street, London, S.W.1. Fuseli came to London at a time when Germany was anxious to establish channels of literary communication with England Among those whose acquaintance he cultivated was Johnson, the radical bookseller of St. Paul's churchyard, where Priestley usually stayed when he came from the provinces to the metropolis. Both Fuseli and Priestley were in holy orders, occupied occasionally with pamphleteering and possessing considerable linguistic abilities. In Thorpe's "History of Chemistry" is a portrait of Priestley delineated by Fuseli in which the discoverer of oxygen is depicted with more femininity of expression than is usually associated with such a free lance. Fuseli became one of the 'lions' of London society and an indispensable guest at many a fashionable dinner table. He was buried in St. Paul's Cathedral between the graves of Opie and Reynolds.

\section{Professor of Astronomy at the Royal Institution}

AT the general monthly meeting of the members of the Royal Institution, held on April 1, it was resolved to establish a professorship of astronomy. Sir James Jeans was nominated, and in the event of his election at the ballot on May 7, will become the first professor of astronomy in the Institution. The last occasion when a new chair was created was the year 1863. This was for Dr. (afterwards Sir Edward) Frankland, who was elected to a separate professorship of chemistry while Faraday was still the Fullerian professor of chemistry. Frankland's professor- 
ship lapsed, however, after Faraday's death. The other 'elected' professorship in the Institution at the time, that of natural philosophy, had been established ten years earlier, and was not so short-lived. It was created for Tyndall when he went to the Institution in 1853, and since his retirement in 1887 has con. tinued by election and re-election down to the present day. Sir James Jeans has thus been nominated to the first new professorship to be established in the Royal Institution for some seventy years. It is also the first chair of astronomy in the history of the Institution.

\section{Revision of Ordnance Survey Maps}

DURING last autumn, the council of the Chartered Surveyors' Institution decided to press for an official inquiry into the present position of the maps and plans of the Ordnance Survey, and an article on the subject appeared in Nature of November 3 (p. 677). In reply to a question by Sir Francis Fremantle in the House of Commons on April 1, Mr. Walter Elliot, Minister of Agriculture, said : "A substantial addition has been made to the Ordnance Survey Estimates for 1935 , and this will enable a beginning to be made in the way of overtaking arrears. I propose, however, to refer to a Departmental Committee the whole question of the acceleration of the revision of Ordnance Survey maps and the preparation of plans for town and country planning. I hope shortly to be able to announce the composition of the committee and its terms of reference."

\section{Model of the Rocket}

A FULL-SIZE replica of the locomotive Rocket, as originally designed and constructed by Robert and George Stephenson, has now been acquired for the National Collections in the Science Museum, and will be unveiled by Mr. L. Hore-Belisha, Minister of Transport, at noon on April 11. The model has been made by Messrs. Robert Stephenson and Co., the firm which built the original engine, and represents it, as nearly as possible, in form, materials and workmanship, as it originally appeared. The original engine was built to compete at the Rainbill Trials in October 1829, which was perhaps the most important event in early locomotive history. The success of Stephenson and Booth's Rocket, which won the premium of $£ 500$ offered by the directors of the Liverpool and Manchester Railway for the most improved locomotive engine constructed in accordance with certain conditions, definitely proved the suitability of the locomotive as a means of general railway haulage, and showed that speeds hitherto unapproached could be attained. The engine was entered by George and Robert Stephenson and Henry Booth. Its success was mainly due to the adoption of the tubular boiler, which was suggested to George Stephenson by Booth. While George Stephenson is popularly credited with the design of the Rocket, its actual construction, at Newcastle, was carried out by his son Robert, the father's time being fully occupied with the making of the railway itself.

\section{Co-operation between the Chemical Societies of Great} Britain

There has recently been circulated to all members of the Chemical Society, the Institute of Chemistry and the Society of Chemical Industry a draft agreement between the three Societies in regard to cooperation. The adoption of the agreement is unanimously recommended by the Council of the Society. of Chemical Industry and the draft agreement was published in Chemistry and Industry on March 15. The agreement provides for the establishment of a fund to be administered by a Chemical Council consisting of three members nominated by the Council of each Society, together with three representatives of industry, co-opted in the first instance on the nomination of the Association of British Chemical Manufacturers. The objects of the fund are the allocation of grants to the constituent bodies for the co-ordination of scientific publications, promotion of research, maintenance of a library, etc. Complete freedom of action is reserved to each constituent body in respect of the matter it publishes. The management of the library of the Chemical Society is delegated to a joint library committee, and contributions to the net annual maintenance expenditure are to be borne by the constituent bodies in proportion to their membership, with due allowance for overlap. This involves, for example, an increase in the contribution of the Institute of Chemistry to $£ 654$ and from the Society of Chemical Industry to £448. The agreement is for seven years and thereafter to continue for successive periods of three years, subject to right of withdrawal on giving one year's notice at the end of any period. If the agreement succeeds, it is anticipated that means of reducing subscriptions to the three organisations will be found.

\section{American Chemical Industry}

THE American Chemical Society is holding in conjunction with its annual meeting in New York on April 22, what may prove to be the largest scientific assembly in history. The object is to expound and commemorate the development of the American chemical industry since its foundation three hundred years ago by John Winthrop Jr., son of the pilgrim Governor of the Massachusetts Colony. In 1633 he set up in Boston the first chemical laboratory and library in the United States, for which he imported apparatus, chemicals and chemical books, and two years later when he became the first colonial Governor of Connecticut, he mapped out a far-reaching programme of local industries including the production of salt, iron, potash, tar, black lead, saltpetre, medicines, copper, alum and other chemicals. Some of these chemicals were made for local use; the chemicals of the forest were exported. It was at Winthrop's suggestion that Massachusetts passed a law in 1642 requiring every town to collect manures to make saltpetre. Chemical industry in the modern sense did not begin in the United States until 150 years later, when in 1792 the manufacture of sulphuric acid was commenced in Philadelphia by John Harrison. 